\title{
Miliary cerebral calcifications
}

\section{A rare presentation of breast cancer metastasis}

Figure 1 CT brain shows multiple small calcified lesions localized in the brainstem, cerebellum, and cerebral hemispheres

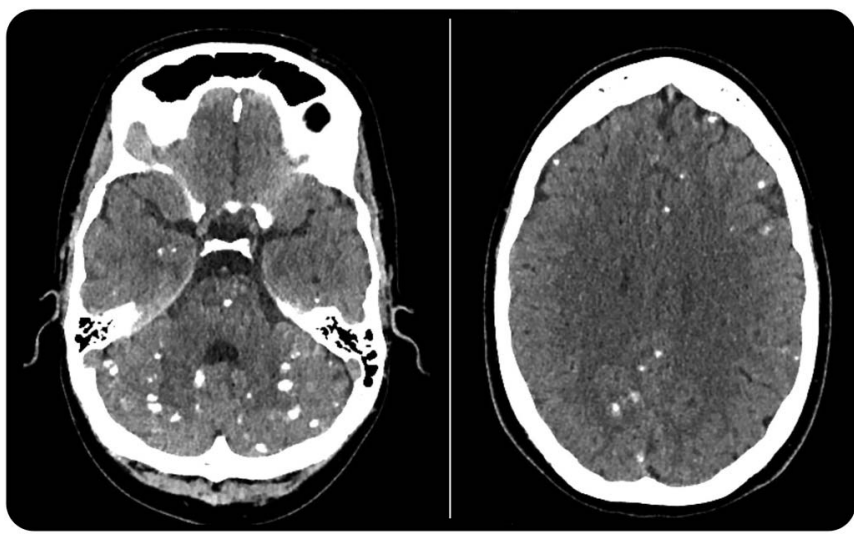

Figure 2 MRI shows small ring-like contrast-enhancing lesions intraparenchymally and following the course of the folia in the cerebellum

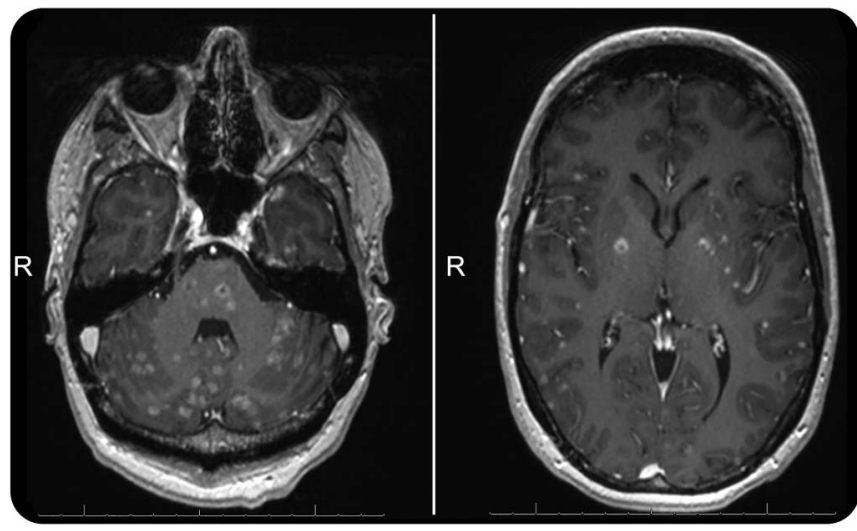

A 38-year-old woman with a history of breast cancer presented with dysarthria and limb ataxia. She reported a traveling history with destinations in Asia over the past 10 years. CT showed small calcified lesions (figure 1). MRI showed more small ring-like contrast-enhancing intraparenchymal lesions that followed the course of sulci and folia (figure 2). Differential diagnosis included metastasis and neurocysticercosis. Examination of CSF showed no evidence of malignancy or infection. Definitive diagnosis after brain biopsy confirmed metastasis of breast cancer. ${ }^{1}$

Laura M.E. de Ceuster, MD, Sebastiaan F.T.M. de Bruijn, MD, PhD, Carel F.E. Hoffmann, MD, PhD

From Hagaziekenhuis, Den Haag, Netherlands.

Author contributions: Dr. Laura M.E. de Ceuster: collecting all clinical data and writing of the manuscript. Dr. Sebastiaan F.T.M. de Bruijn: critical revision of the manuscript for important intellectual content. Dr. Carel F.E. Hoffmann: critical revision of the manuscript for important intellectual content.

Study funding: No targeted funding reported.

Disclosure: The authors report no disclosures relevant to the manuscript. Go to Neurology.org for full disclosures.

Correspondence to Dr. de Ceuster: L.deCeuster@hagaziekenhuis.nl

1. Stadnik T, Deroover J, Gosens A, Michotte A, Freson M, Osteaux M. Calcified, cystic brain metastases. Eur J Radiol 1997;25:36-40. 


\section{Neurology}

\section{Miliary cerebral calcifications: A rare presentation of breast cancer metastasis}

Laura M.E. de Ceuster, Sebastiaan F.T.M. de Bruijn and Carel F.E. Hoffmann Neurology 2016;86;879

DOI 10.1212/WNL.0000000000002424

\section{This information is current as of February 29, 2016}

\section{Updated Information \& Services}

References

Subspecialty Collections

Permissions \& Licensing

Reprints including high resolution figures, can be found at: http://n.neurology.org/content/86/9/879.full

This article cites 1 articles, 0 of which you can access for free at: http://n.neurology.org/content/86/9/879.full\#ref-list-1

This article, along with others on similar topics, appears in the following collection(s):

All Imaging

http://n.neurology.org/cgi/collection/all_imaging Metastatic tumor

http://n.neurology.org/cgi/collection/metastatic_tumor Parasitic infections

http://n.neurology.org/cgi/collection/parasitic_infections

Information about reproducing this article in parts (figures,tables) or in its entirety can be found online at:

http://www.neurology.org/about/about_the_journal\#permissions

Information about ordering reprints can be found online:

http://n.neurology.org/subscribers/advertise

Neurology ${ }^{\circledR}$ is the official journal of the American Academy of Neurology. Published continuously since 1951, it is now a weekly with 48 issues per year. Copyright @ 2016 American Academy of Neurology. All rights reserved. Print ISSN: 0028-3878. Online ISSN: 1526-632X.

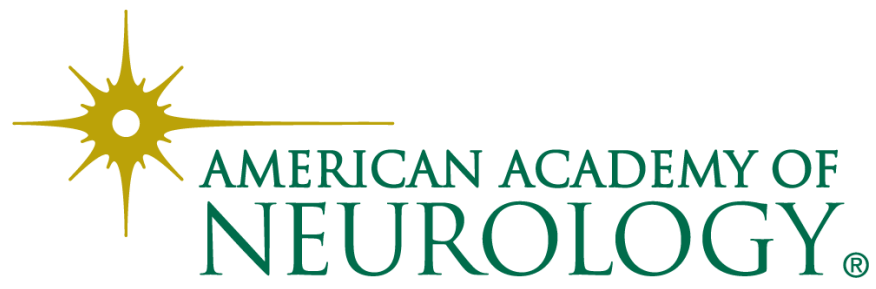

